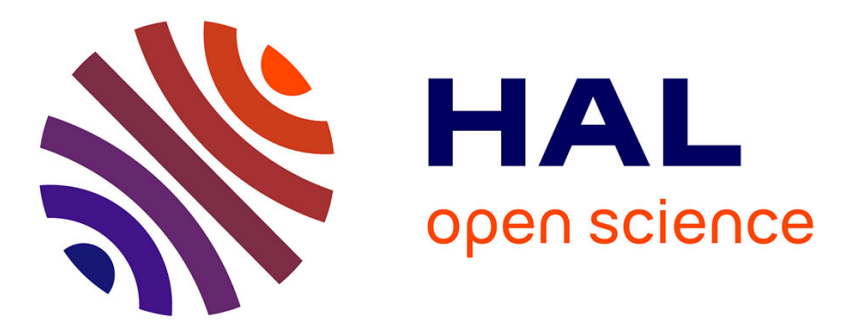

\title{
Geoprospective as a support to marine spatial planning: some French experience-based assumptions and findings
}

Françoise Gourmelon, Brice Trouillet, Romain Legé, Laurie Tissière, Stéphanie Mahévas

\section{To cite this version:}

Françoise Gourmelon, Brice Trouillet, Romain Legé, Laurie Tissière, Stéphanie Mahévas. Geoprospective as a support to marine spatial planning: some French experience-based assumptions and findings. Emmanuel Garbolino; Christine Voiron-Canicio. Ecosystem and Territorial Resilience. A Geoprospective Approach, Elsevier, pp.279-298, 2021, 978-0-12-818215-4. 10.1016/B978-0-12-818215-4.00010-9 . hal-02944023

\section{HAL Id: hal-02944023 \\ https://hal.science/hal-02944023}

Submitted on 26 Nov 2020

HAL is a multi-disciplinary open access archive for the deposit and dissemination of scientific research documents, whether they are published or not. The documents may come from teaching and research institutions in France or abroad, or from public or private research centers.
L'archive ouverte pluridisciplinaire HAL, est destinée au dépôt et à la diffusion de documents scientifiques de niveau recherche, publiés ou non, émanant des établissements d'enseignement et de recherche français ou étrangers, des laboratoires publics ou privés. 


\section{Geoprospective as a support to marine spatial planning: some French experience-based assumptions and findings}

Gourmelon Françoise ${ }^{1}$

Trouillet Brice ${ }^{2}$

Légé Romain ${ }^{2}$

Tissière Laurie ${ }^{2}$

Mahévas Stéphanie ${ }^{3}$

${ }^{1}$ CNRS, UMR LETG, Institut Universitaire Européen de la Mer, Plouzané, France

${ }^{2}$ Université de Nantes, UMR LETG, Nantes, France

${ }^{3}$ Ifremer, Nantes, France

\subsection{Introduction}

With around 60 initiatives worldwide (IOC-UNESCO, EC-DGMARE, 2017), marine spatial planning (MSP) is asserting itself on a global scale in a context of rapid change due to a

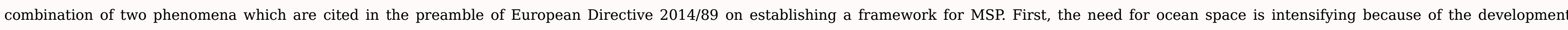

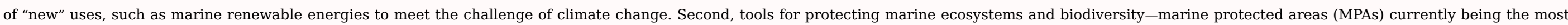
developed of these-are multiplying with the aim of incorporating $10 \%$ of the world's ocean surface area by 2020 (i.e., about 36 million km²) compared with just under $4 \%$ currently. ${ }^{1}$

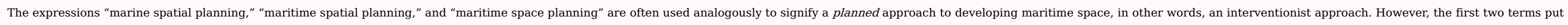

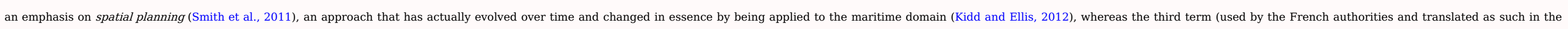

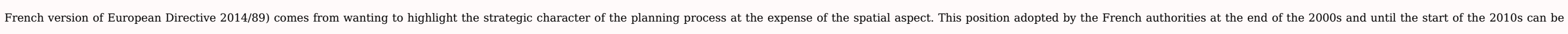

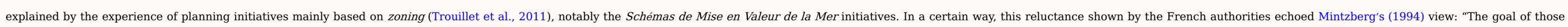

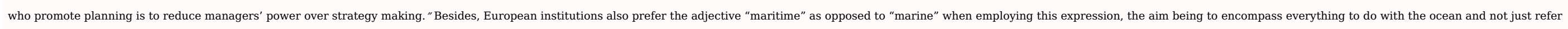
to what is produced by the sea. 


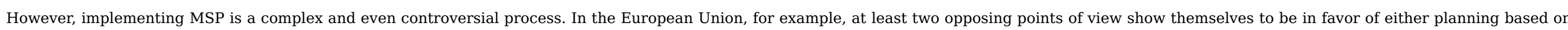

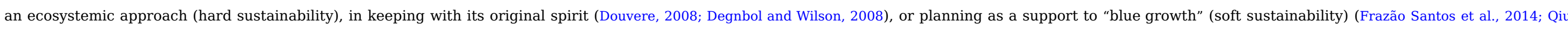
and Jones, 2013). This opposition gives rise to an ambiguity, particularly when it comes to coordinating MSP and PMAs. It also brings the "spatial" aspect into question, which is viewed

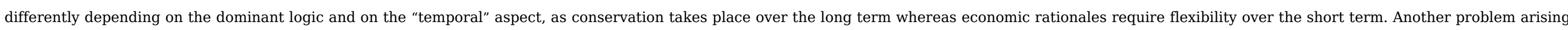

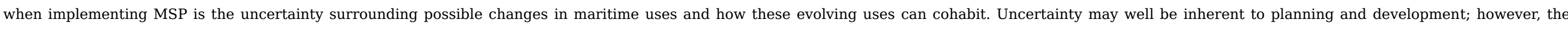

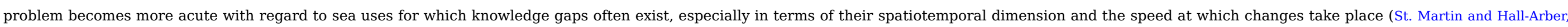
2008).

Page 3

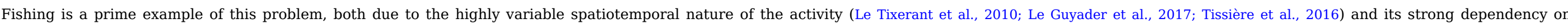

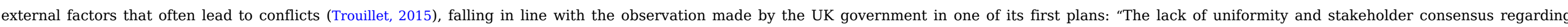

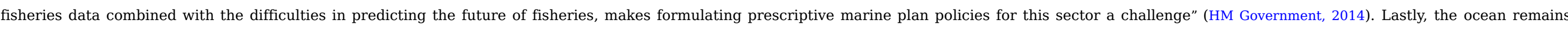

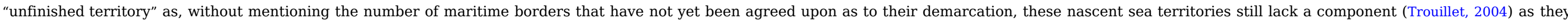

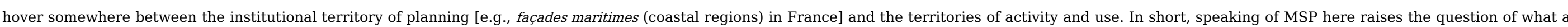
"territory" is and consequently of what "makes" a territory (actors, projects, etc.).

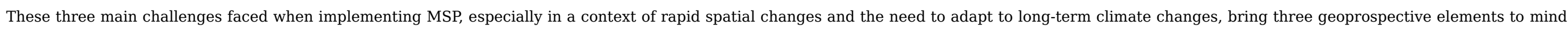

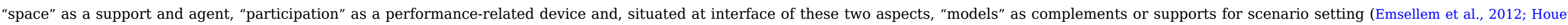

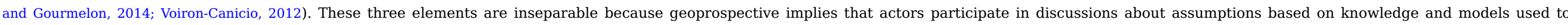

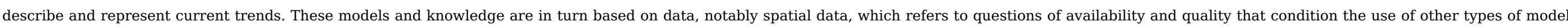
(GIS, simulators, etc.) (Le Tixerant et al., 2018; Pinarbasi et al., 2017).

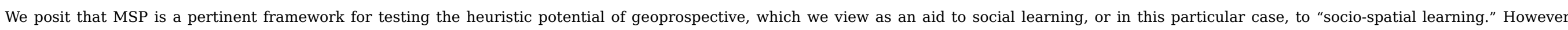

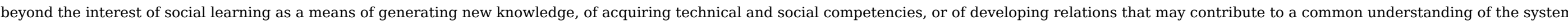

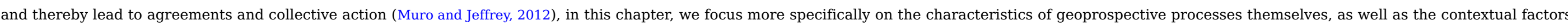

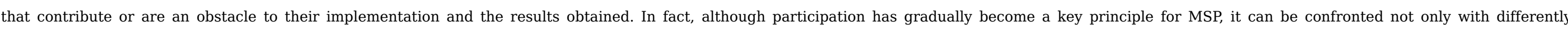

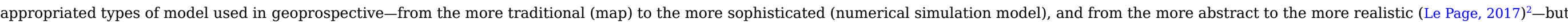

Page 4

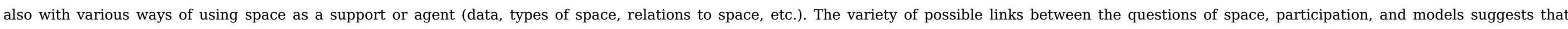
there is a potential for thinking about and using geoprospective in different ways, each way liable to offer advantages and challenges depending on the implementation context and methods.

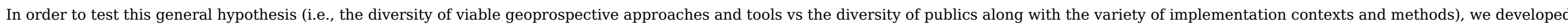
an analysis based on experiments performed over several scales of time and space, with a variety of publics and using different objects (Fig. 10.1). 


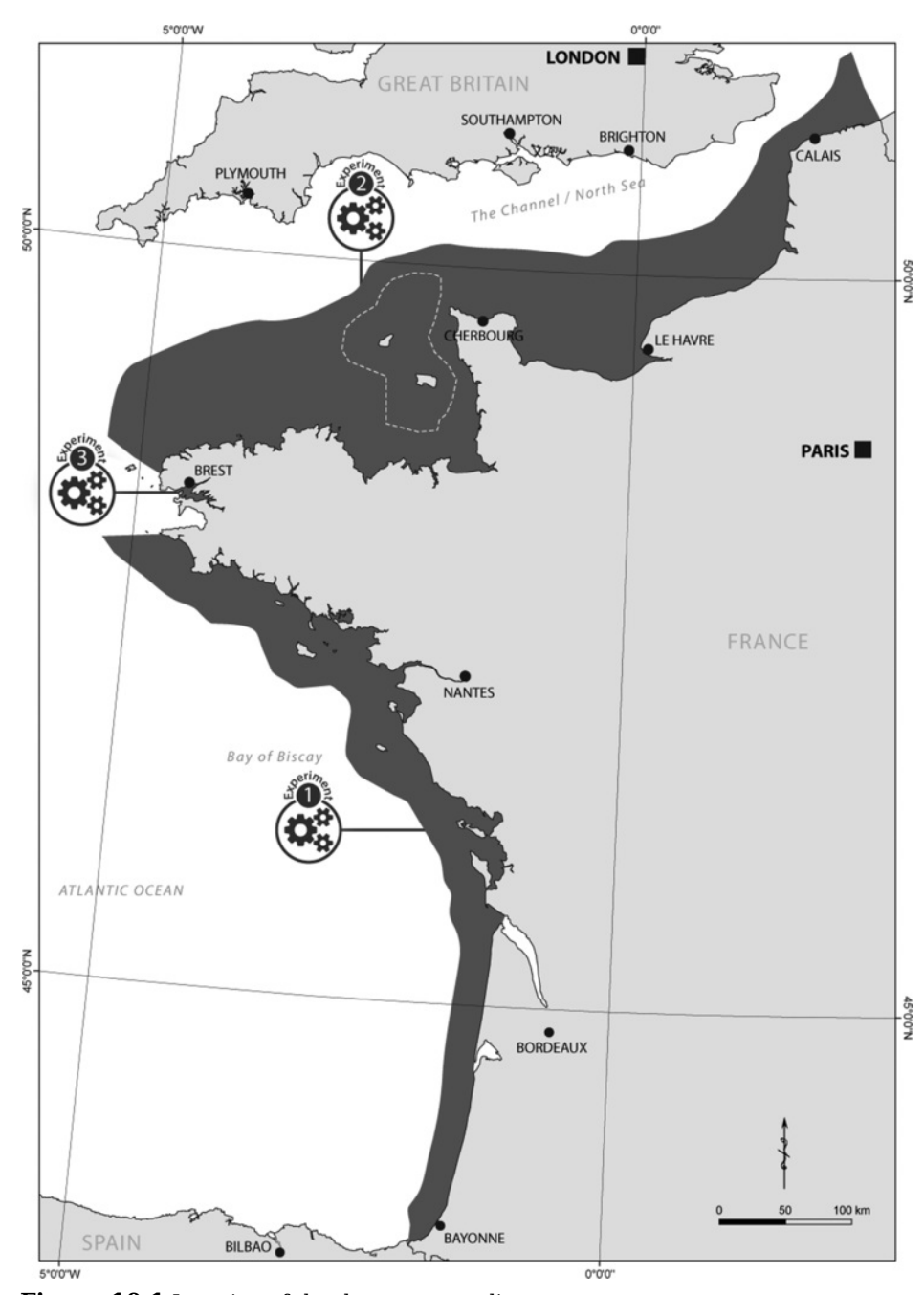

Figure 10.1 Location of the three case studies.

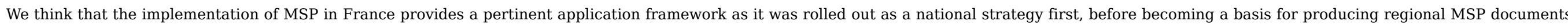

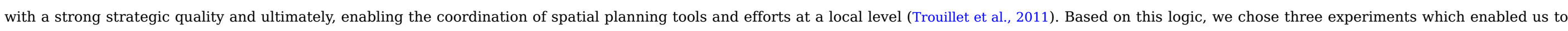

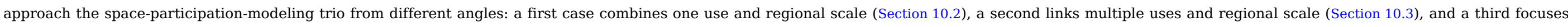
on multiple uses and local scale (Section 10.4). Following on from this, we analyzed the benefits and limits of geoprospective using a discussion grid based on this trio (Section 10.5).

\subsection{A geoprospective experiment concerning one activity on a regional scale}

\subsubsection{Implementation context and objectives}

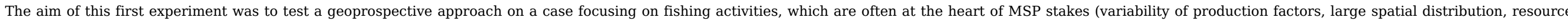

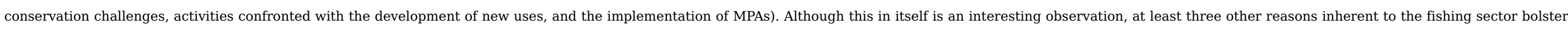




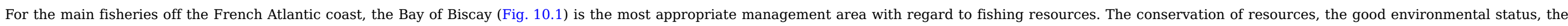
distribution of access to the area, or the renewal of fleets are all important goals for fishery management policies and more broadly,

Page 5

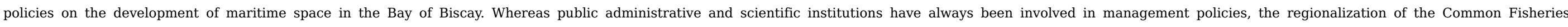

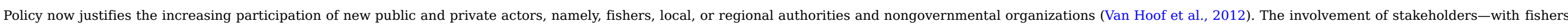

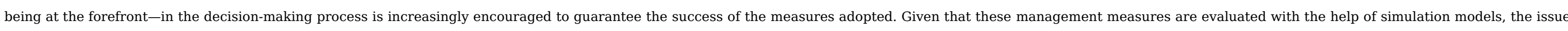

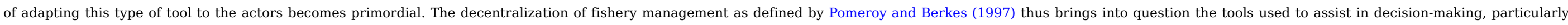
models, which have gradually become more complex to account for the different elements of fishery systems (Thébaud et al., 2014).

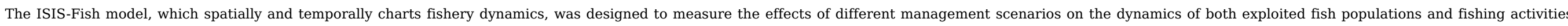

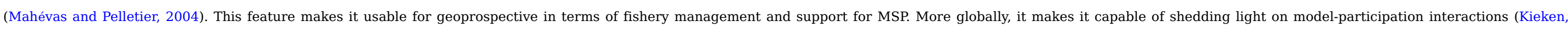

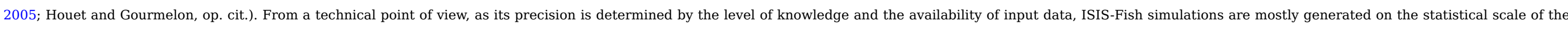

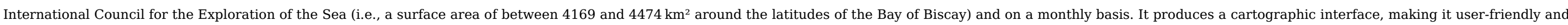
encouraging discussion between actors.

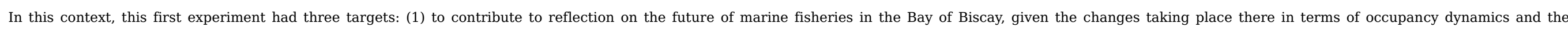
implementation of MSP tools, (2) to accompany the participation of several types of actor, and (3) to analyze the use of tools in a participatory context.

\subsubsection{Methods}

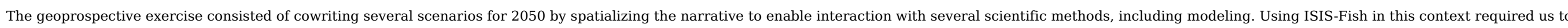

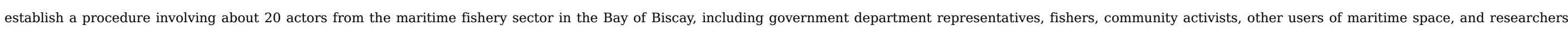
from different disciplines. Three rounds of surveys were led by a foresighter and a geographer, with modelers sometimes brought in to work with them (Fig. 10.2).

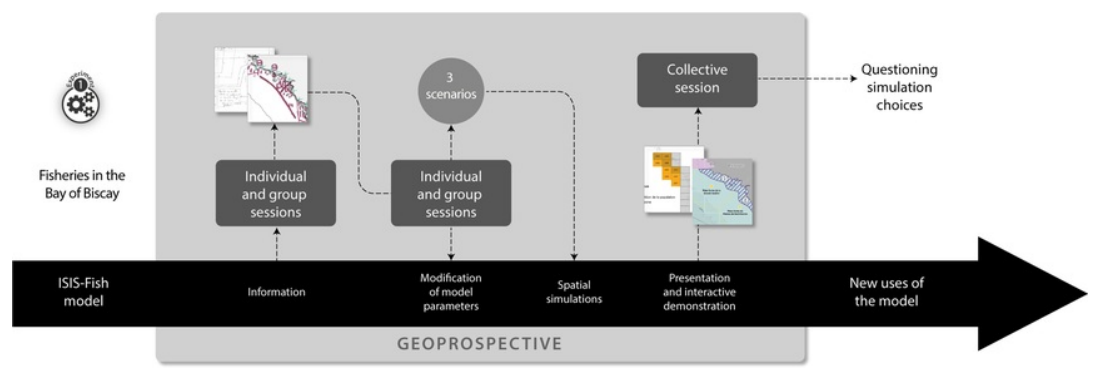

Figure 10.2 Fisheries in the Bay of Biscay: methodology. 


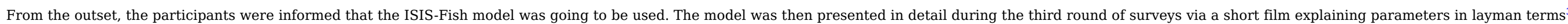

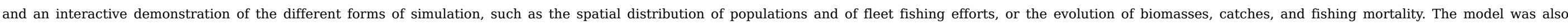
accompanied by different qualitative support materials to enable discussion about its parameters and to cobuild hypotheses to be tested.

\subsubsection{Results}

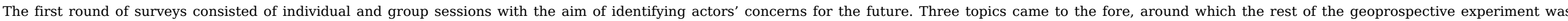

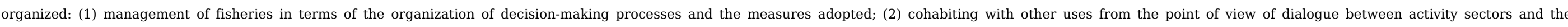

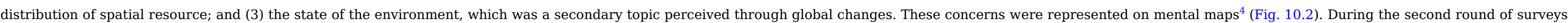

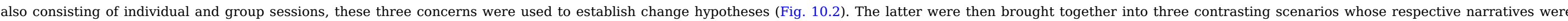

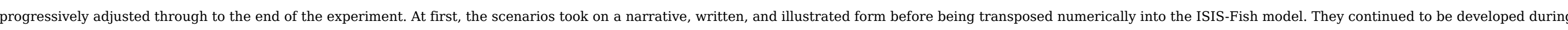
the third

Page 8

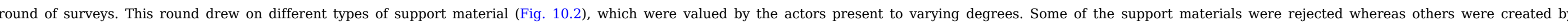
the participants in the same vein as an influence graph, which enabled the chain of causal links for one of the scenarios to be highlighted (Tissière et al., 2018).

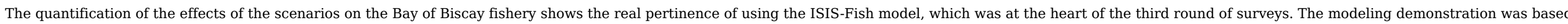

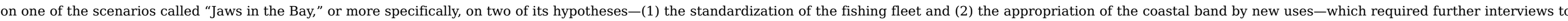

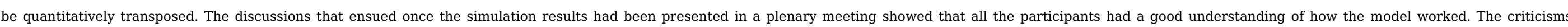
expressed were not aimed at the parameters but at the choices made in transposing the hypotheses (faithfulness to the original narrative, probability of orders of magnitude selected, etc.) (Provost et al.,)

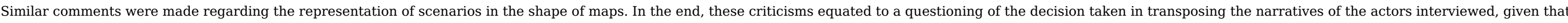
the more strategic aspects of their participation had been formalized.

\subsection{A geoprospective experiment concerning multiple uses on a regional scale}

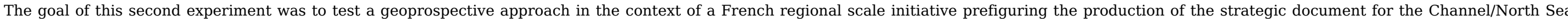
French coastal region.

\subsubsection{Implementation context and objectives}

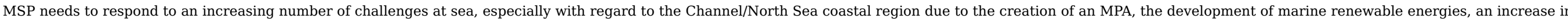

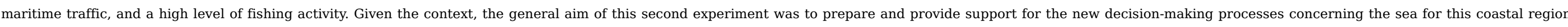
(Fig. 10.1).

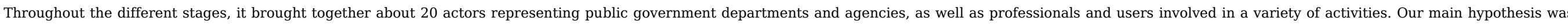
first that participation in a geoprospective experiment would encourage the convergence of perceptions held by actors with different 


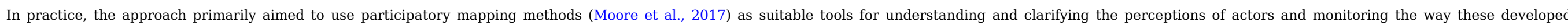

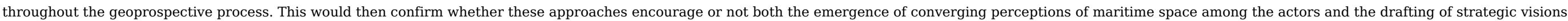

\subsubsection{Methods}

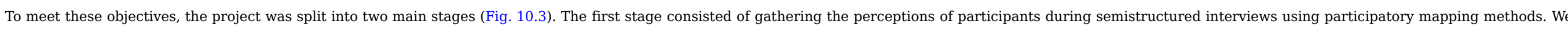

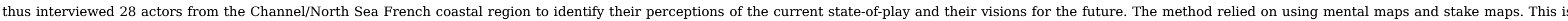

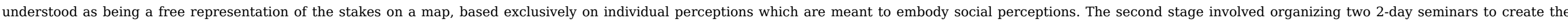

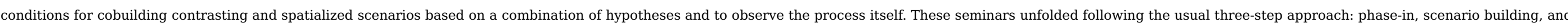

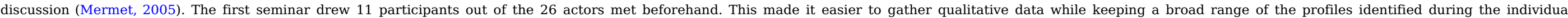
interviews. Three months later, the second seminar counted 10 participants, all of which had been present at the first

Page 10

seminar, ensuring continuity in our experiment. The aim was not so much representativeness as to check our main hypothesis.

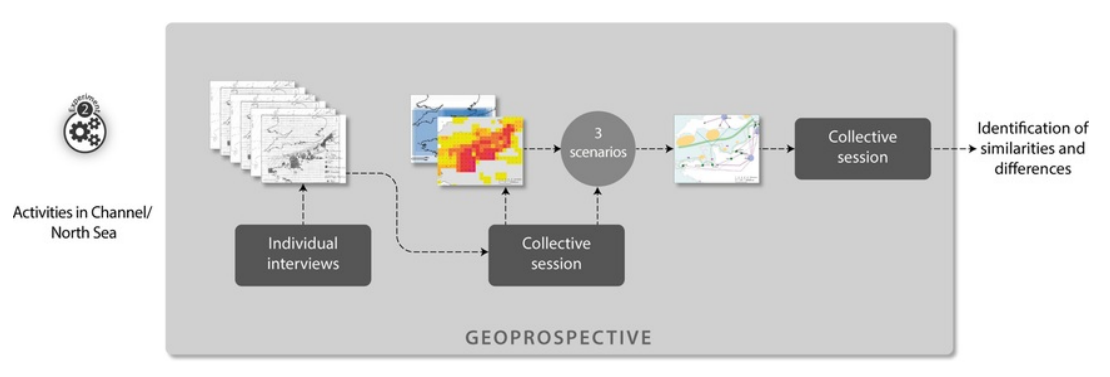

Figure 10.3 Activities in the Channel/North Sea: methodology

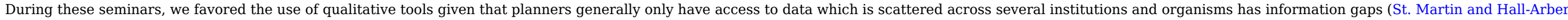

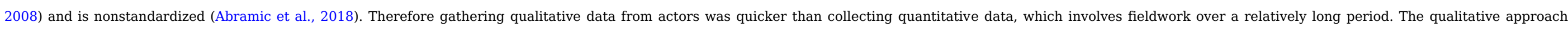

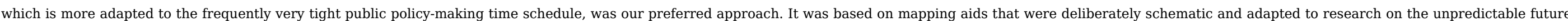
of vast entities.

\subsubsection{Results}

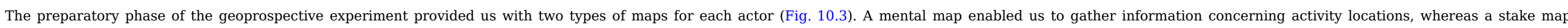
encouraged a first step toward identifying perceptions by asking actors to spatialize and qualify these stakes (i.e., activities and actors concerned, major changes to be anticipated, trends, etc.).

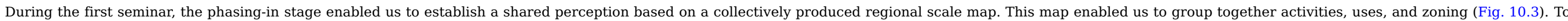




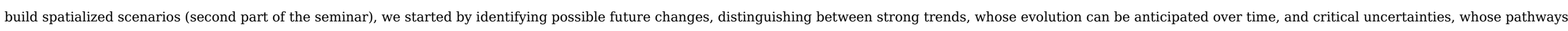

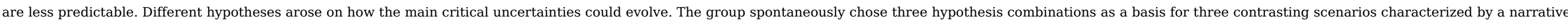

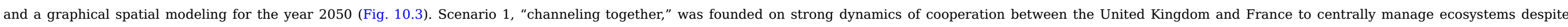

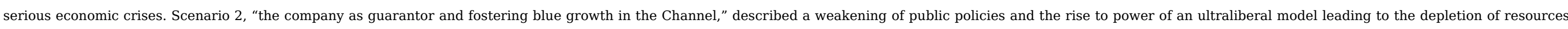

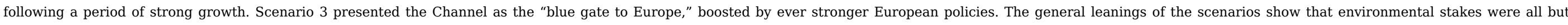

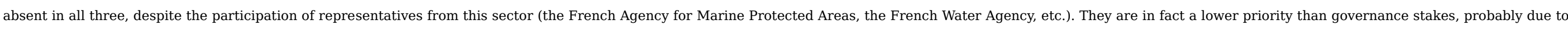
the political context in which the exercise took place, that is, the reorganization of government departments coupled with the rise of MSP. The link between current events and

Page 11

the "game" proposed by the workshop seemed obvious, both in the opinions held by the actors and the scenarios themselves.

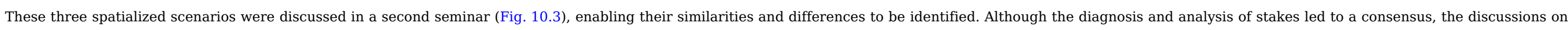
the solutions to be adopted to meet these challenges did not result in a shared strategic vision common to all the participants.

\subsection{A geoprospective experiment concerning multiple uses on a local scale}

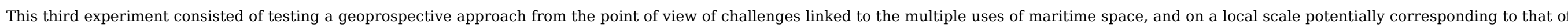
the spatial planning tools (e.g., marine natural parks) which need to be coordinated in the local strategic documents.

\subsubsection{Implementation context and objectives}

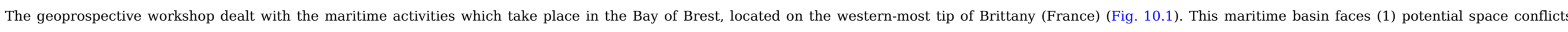

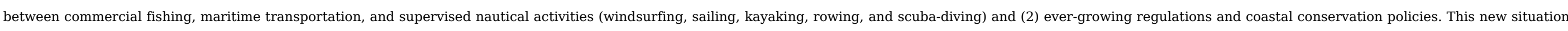

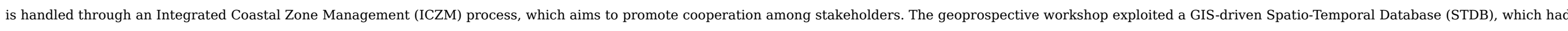

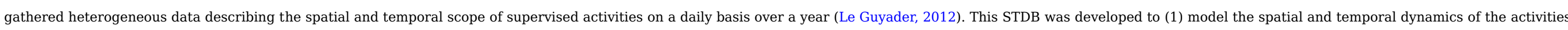

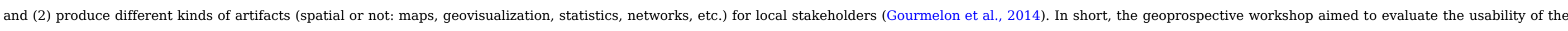
STDB in a professional context as a support for debates as well as a way to optimize the simulation based on the collective scenario process, while providing different types of representations.

\subsubsection{Methods}

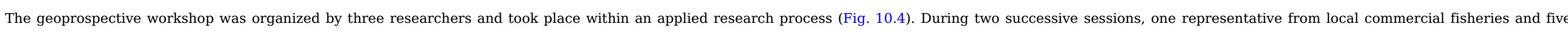
representatives from local agencies involved in the management of the Bay of Brest were brought together. Government departments and

Page 12

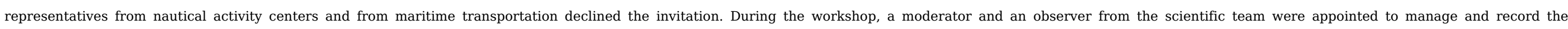
reactions and debates between the participants. 


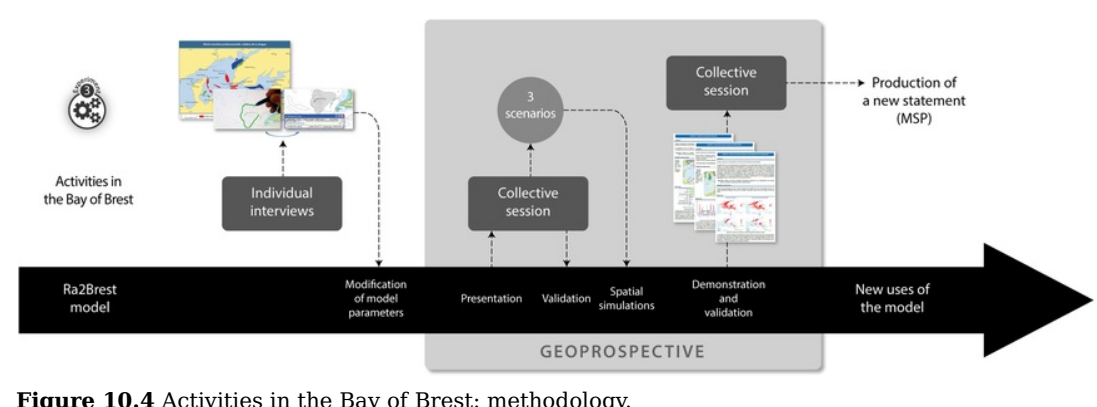

Figure 10.4 Activities in the Bay of Brest: methodology.

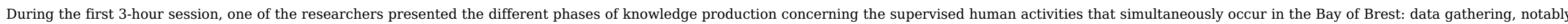

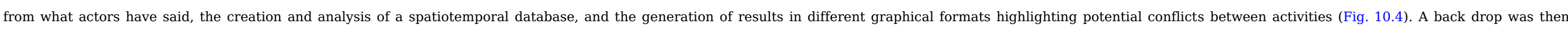

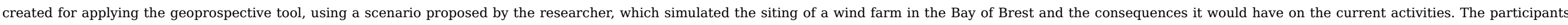
were then invited to propose future scenarios for maritime activities in the Bay of Brest.

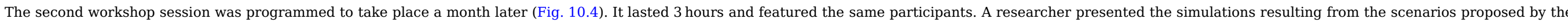

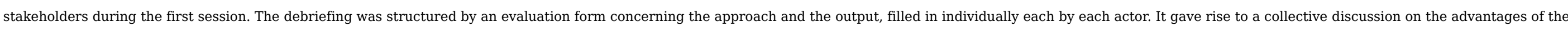
geoprospective approach in this kind of application context and notably, the benefits of the spatiotemporal aspect of representations.

\subsubsection{Results}

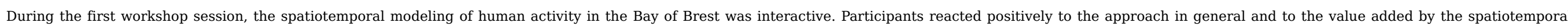
aspect. Spatiotemporal interactions between

Page 13

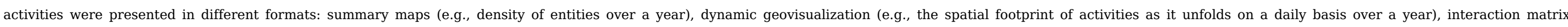

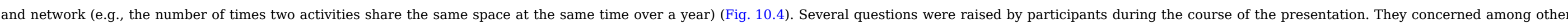

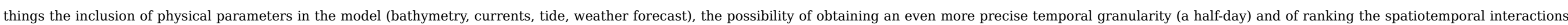

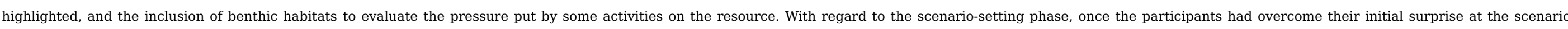

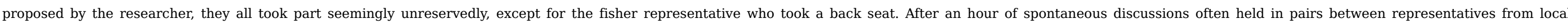

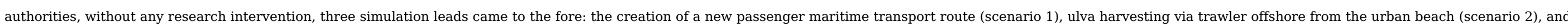
reintroduction of marine aquaculture (scenario 3). These three scenarios were essentially proposed by three local authority representatives.

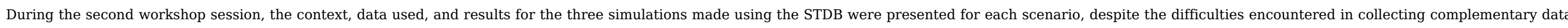

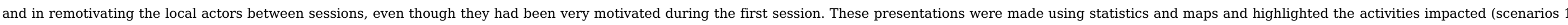

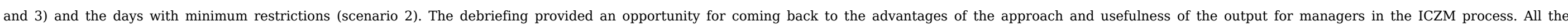

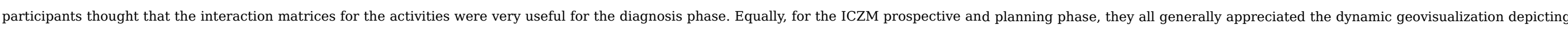

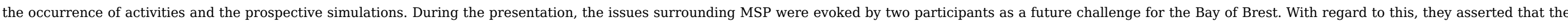

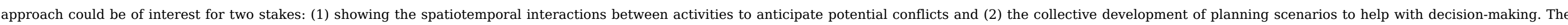




\subsection{Discussion-Conclusion}

The common objective of these three geoprospective experiments was to test the advantages and limits of this approach in terms of social learning, with a focus on the role of the

Page 14

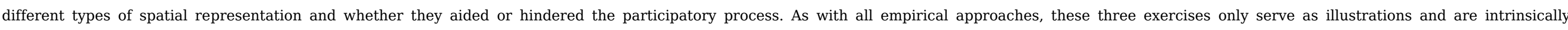

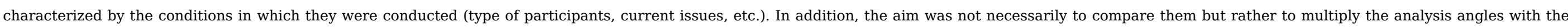

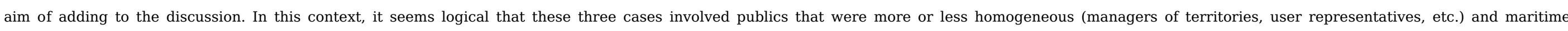

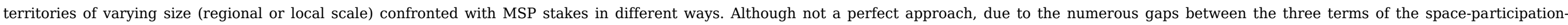
modeling trio, it can still serve as a guide for transversal analysis, aimed at gaining knowledge on applying geoprospective to the maritime area in terms of planning.

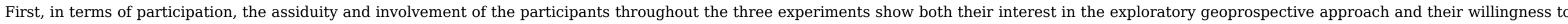

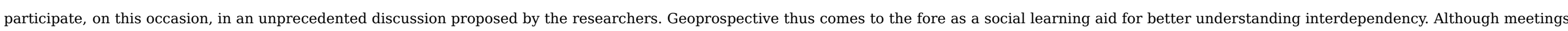

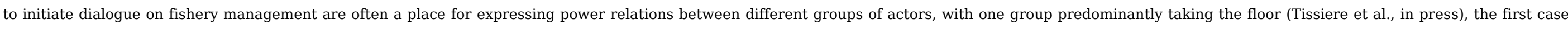

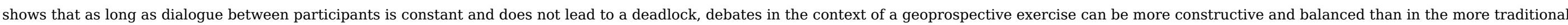

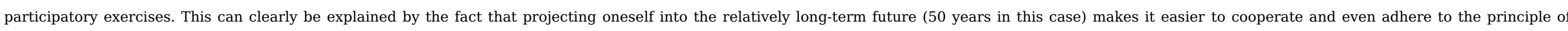

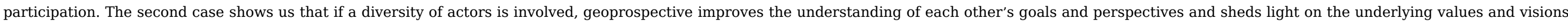

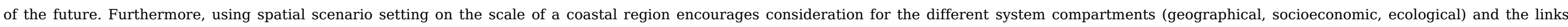

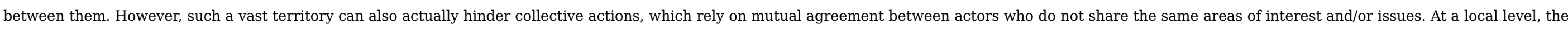

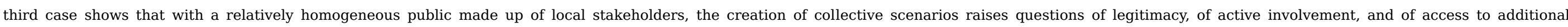

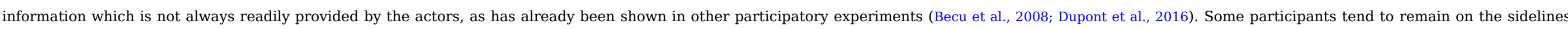

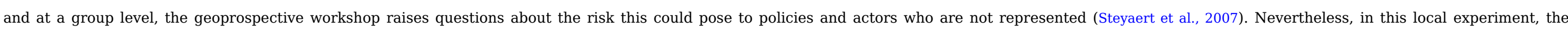
geoprospective approach taken as a whole helped not only to encourage actors to cooperate at certain times, but also to produce a new statement to

Page 15

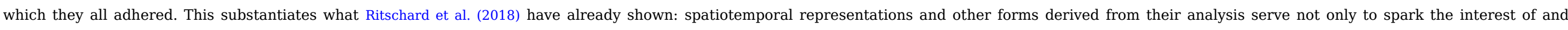
enroll stakeholders in a participatory process, but also to smooth the way for the emergence of a collective statement of new stakes for the territory.

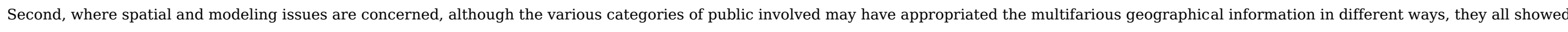

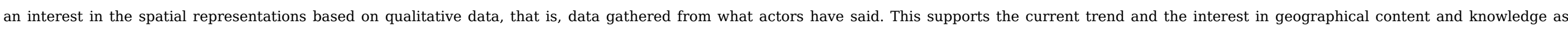

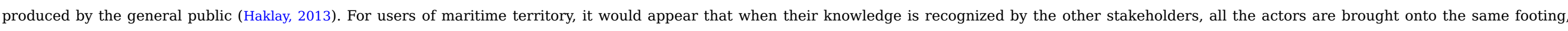

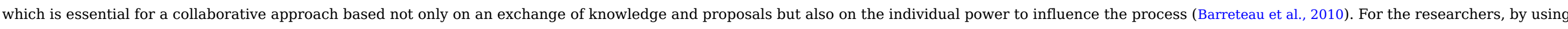

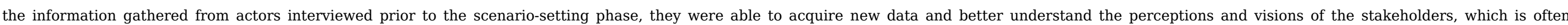




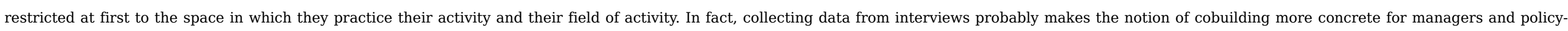

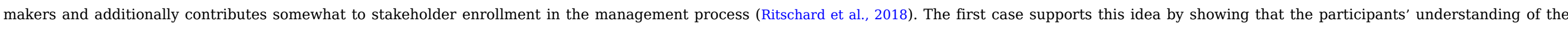

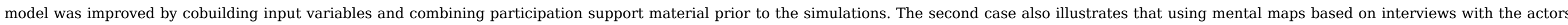

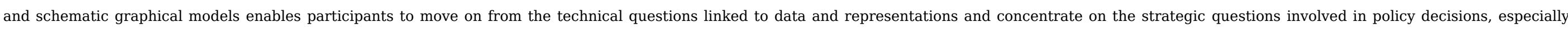

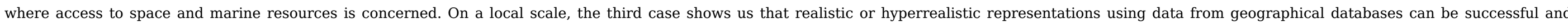

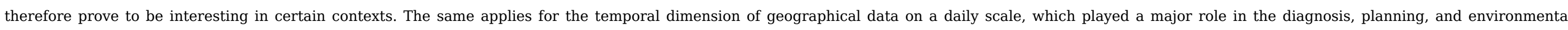

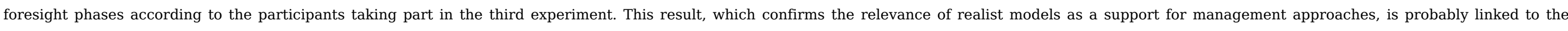

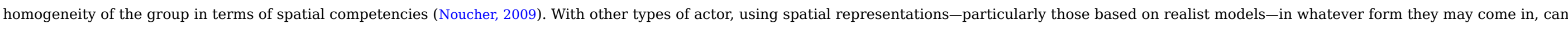

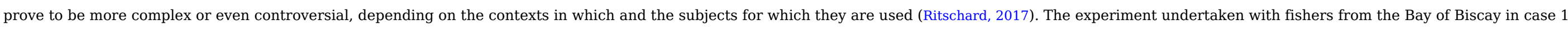
illustrates this situation. The spatial dimension became a mediator when it gave rise to stakes shared by the different categories of participants, both in terms of the fishing

Page 16

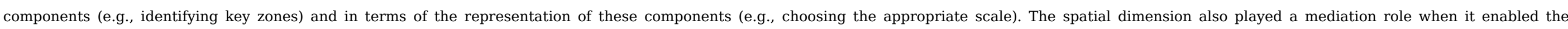

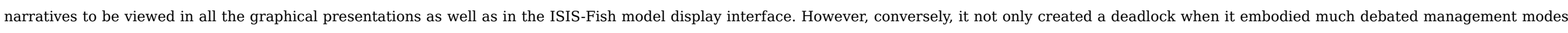

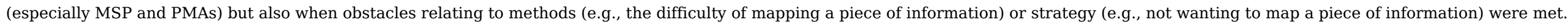

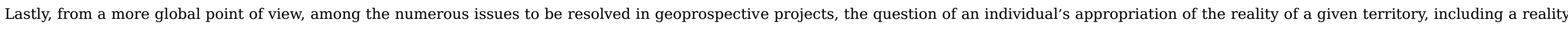

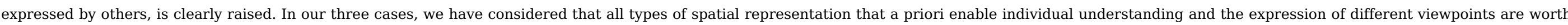

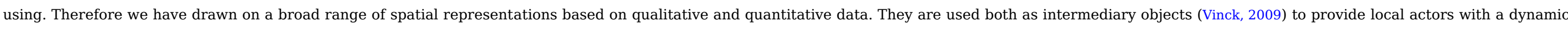

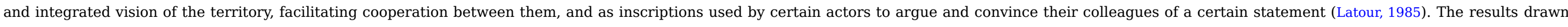

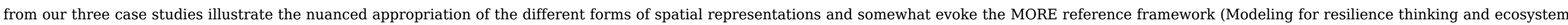
stewardship) proposed by Schlüter et al. (2013) in socioecological system models (Fig. 10.5).

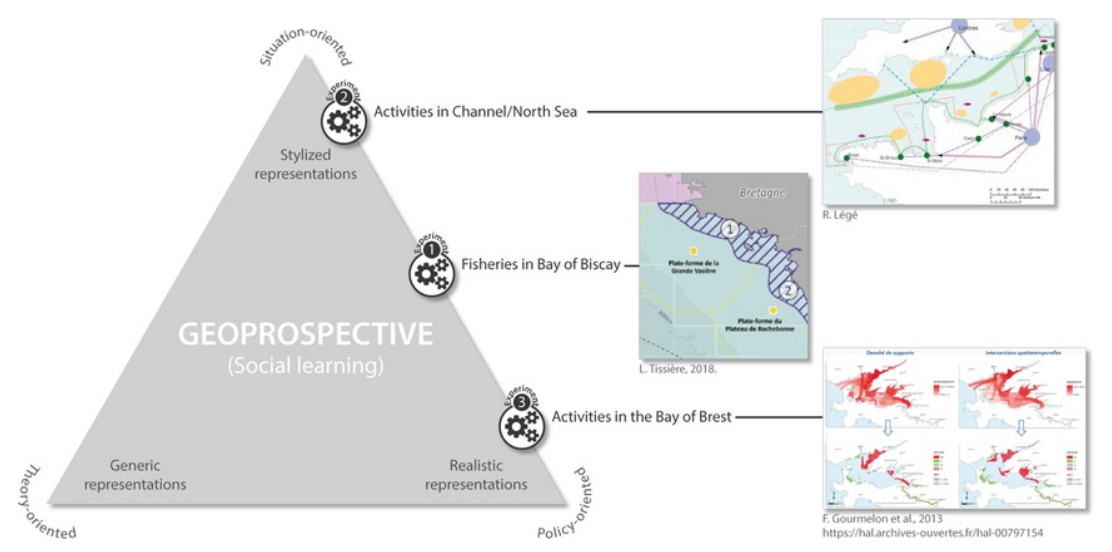

Figure 10.5 The different forms of spatial representations produced by the three geoprospective experiments versus MORE reference framework (Schlüter et al., 2013). 


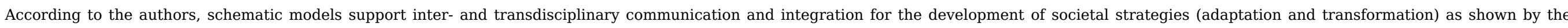

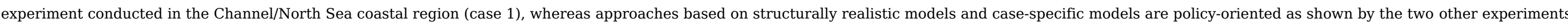

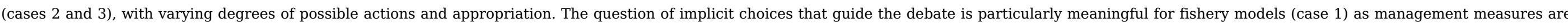

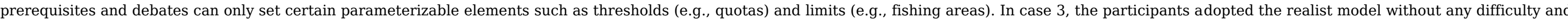
"played along" during the scenario-setting phase. Their level of innovation with regard to possible futures was nevertheless limited by their feeling of illegitimacy in taking decisions.

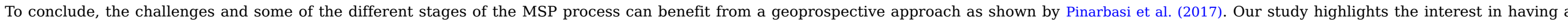

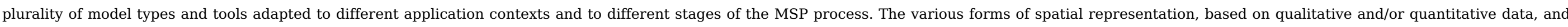

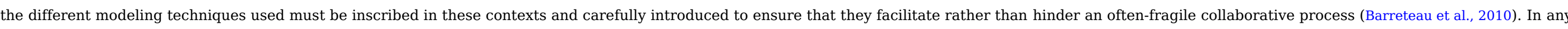
case, further evidence of the beneficial outcomes is now required, which justifies the increasing number of new experiments

\section{Acknowledgments}

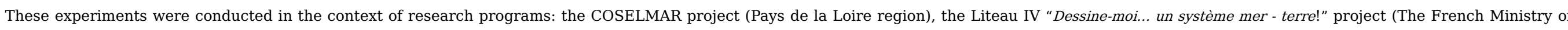

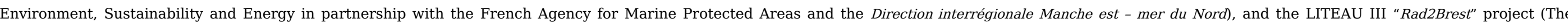

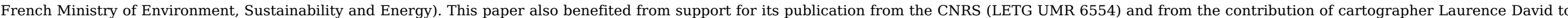

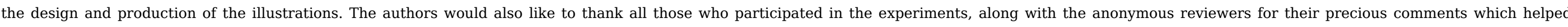
improve the first draft of this paper.

\section{References}

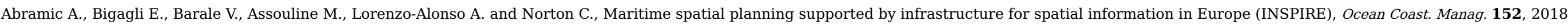
23-36. https://doi.org/10.1016/j.ocecoaman.2017.11.007.

Barreteau O., Bots P. and Daniell K., A framework for clarifying participation in participatory research to prevent its rejection for the wrong reasons, Ecol. Soc. 15 (2), 2010, 1-22,

$<$ http://www.ecologyandsociety.org/vol15/iss2/art1/>.

Page 18

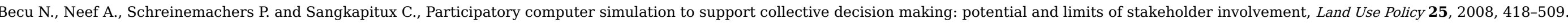
https://doi.org/10.1016/j.landusepol.2007.11.002.

Degnbol D. and Wilson D.C., Spatial planning on the North Sea: a case of cross-scale linkages, Mar. Policy 32 (2), 2008, 189-200. https://doi.org/10.1016/j.marpol.2007.09.006.

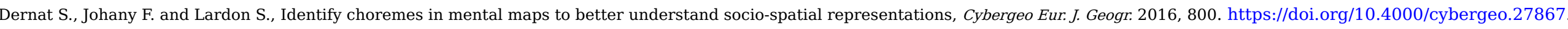

Douvere F., The importance of marine spatial planning in advancing ecosystem-based, sea use management, Mar. Policy 32 (5), 2008, 762-771. https://doi.org/10.1016/j.marpol.2008.03.021.

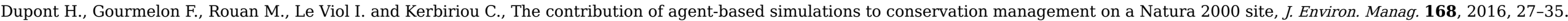

https://doi.org/10.1016/j.jenvman.2015.11.056. 
Emsellem K., Liziard S. and Scarella F., La géoprospective: l'émergence d'un nouveau champ de recherche, L'Espace Géogr. 41 (2), 2012, 154-168. https://doi.org/10.3917/eg.412.0154.

Frazão Santos C., Domingos T., Ferreira M.A., Orbach M. and Andrade F., How sustainable is sustainable marine spatial planning? Part I-Linking the concepts, Mar. Policy 49, 2014, 59-65. https://doi.org/10.1016/j.marpol.2014.04.004.

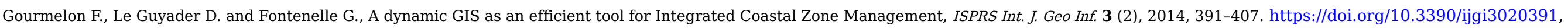
<http://www.mdpi.com/2220-9964/3/2/391>.

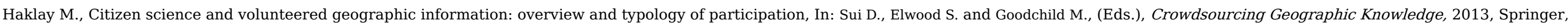
Dordrecht, 105-122, <http://link.springer.com/chapter/10.1007/978-94-007-4587-2_7>.

HM Government, East Inshore and East Offshore Marine Plans, 2014, Department for Environment, Food and Rural Affairs, London, 193.

Houet T. and Gourmelon F., La géoprospective. Apport de la dimension spatiale aux démarches prospectives, Cybergeo Eur. J. Geogr. 2014. https://doi.org/10.4000/cybergeo.26194.

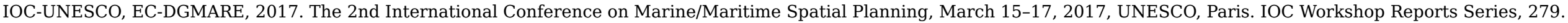

Kidd S. and Ellis G., From the land to sea and back again? Using terrestrial planning to understand the process of marine spatial planning, J. Environ. Policy Plan. 14 (1), 2012 , 49-66. https://doi.org/10.1080/1523908X.2012.662382.

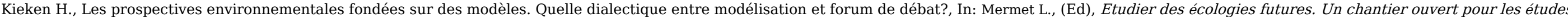
prospectives environnementales, 2005, EcoPolis. P.I.E. Peter Lang, Bruxelles.

Latour M., Les “vues” de l'esprit, Cult. Tech. 14, 1985, 4-29.

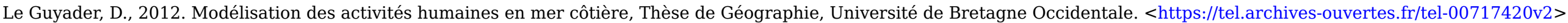

Le Guyader D., Ray C., Gourmelon F. and Brosset D., Defining high resolution dredges fishing grounds with automatic identification system (AIS) data, Aquat. Living Resour. 30 (39), 2017, 1-10. https://doi.org/10.1051/alr/2017038.

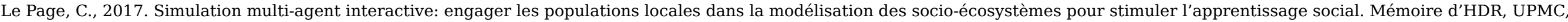
<https://collaboratif.cirad.fr/alfresco/s/d/workspace/SpacesStore/45d837d8-da99-46a2-90b0-17487d15e94d/LePage_2017_DossierHDR.pdf>.

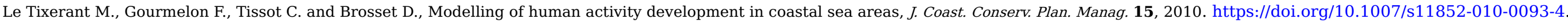

Le Tixerant M., Le Guyader D., Gourmelon F. and Quéfellec B., How can Automatic Identification System (AIS) data be used for maritime spatial planning?, Ocean Coast. Manag. 166, 2018. https://doi.org/10.1016/j.ocecoaman.2018.05.005

Page 19

Mahévas S. and Pelletier D., ISIS-Fish, a generic and spatially explicit simulation tool for evaluating the impact of management measures on fishery dynamics, Ecol. Model. 171, 2004, 65-84. https://doi.org/10.1016/j.ecolmodel.2003.04.001.

Mermet L., (dir.), Étudier des écologies futures, Un. chantier Ouvert. pour les. Rech. prospectives environnementales 5, 2005, P.I.E.-Peter Lang, EcoPolis.

Mintzberg, H., 1994. The Rise and Fall of Strategic Planning. Harvad Business Review. January-February, pp. 107-114. 
Moore S., Brown G., Kobryn H. and Strickland-Munro J., Identify conflict potential in a coastal and marine environment using participatory mapping, J. Environ. Manag. 197, 2017, 706-718. https://doi.org/10.1016/j.jenvman.2016.12.026.

Muro M. and Jeffrey P., A critical review of the theory and application of social learning in participatory natural resource management processes, J. Environ. Plan. Manag. 51 (3), 2012, 325-344. https://doi.org/10.1080/09640560801977190.

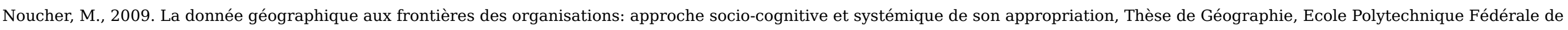
Lausanne (EPFL). <https://halshs.archives-ouvertes.fr/tel-00654203/document>.

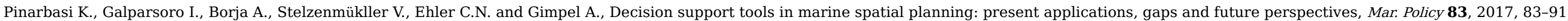
https://doi.org/10.1016/j.marpol.2017.05.031.

Pomeroy R.S. and Berkes F., Two to tango: the role of government in fisheries co-management, Mar. Policy 21 (5), 1997, 465-480. https://doi.org/10.1016/S0308-597X(97)00017-1.

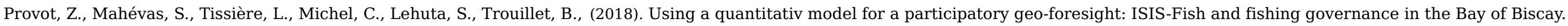
Mar. Policy. (https://doi.org/10.1016/j.marpol.2018.08.015)

Qiu W. and Jones P.J.S., The emerging policy landscape for marine spatial planning in Europe, Mar. Policy 39, 2013, 182-190. https://doi.org/10.1016/j.marpol.2012.10.010.

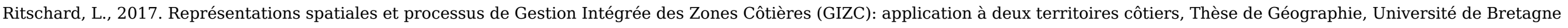
Occidentale. <https://tel.archives-ouvertes.fr/tel-01512946>.

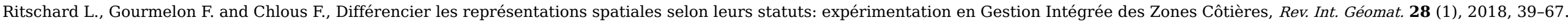
https://doi.org/10.3166/rig.2017.00037.

Schlüter, M., Müller, B., Frank, K., 2013. How to use models to improve analysis and governance of social-ecological systems. The reference frame MORE. Working paper. <http://ssrn.com/abstract=2037723>.

Smith H.D., Maes F., Stojanovic T.A. and Ballinger R.C., The integration of land and marine spatial planning, J. Coast. Conserv. 15, 2011, 291-303. https://doi.org/10.1007/s11852-010-0098-Z.

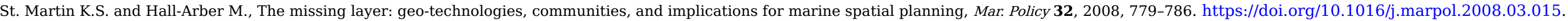

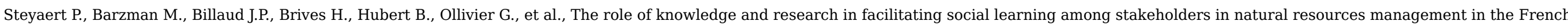
Atlantic coastal wetlands, Environ. Sci. Policy 10, 2007, 537-550. https://doi.org/10.1016/j.envsci.2007.01.012.

Thébaud O., Doyen L., Lample M. and Mahévas S., Building ecological-economic models and scenarios of marine resource systems: workshop report, Mar. Policy 43, 2014, 382-386. https://doi.org/10.1016/j.marpol.2013.05.010.

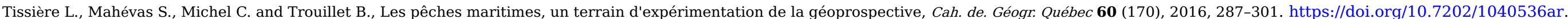
Tissière L., Mahévas S. and Trouillet B., Findings from an exploratory study on the governance of a French fishery, Mar. Policy 2018. https://doi.org/10.1016/j.marpol.2018.01.028. 
Trouillet B., Les enjeux spatiaux: la reconfiguration des espaces halieutiques, In: Guillaume J., (Ed), Espaces Maritimes et Territoires Marins, 2015, Ellipses, Paris, 53-88.

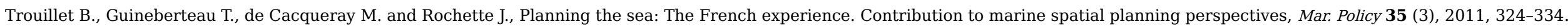
https://doi.org/10.1016/j.marpol.2010.10.012.

Van Hoof L., Van Leeuwen J. and Van Tatenhove J., All at sea; regionalisation and integration of marine policy in Europe, Marit. Stud. 11 (9), 2012 ,

<https://maritimestudiesjournal.springeropen.com/articles/10.1186/2212-9790-11-9>.

Vinck D., De l'objet intermédiaire à l'objet frontière. Vers la prise en compte du travail d'équipement, Rev. D'anthropol. Connaiss. 3 (1), 2009, 51-72. https://doi.org/10.3917/rac.006.0051.

Voiron-Canicio C., L'anticipation du changement en prospective et des changements spatiaux en géoprospective, L'Espace Géogr. 41 (2), 2012, 99-110. https://doi.org/10.3917/eg.412.0099.

\section{Further reading}

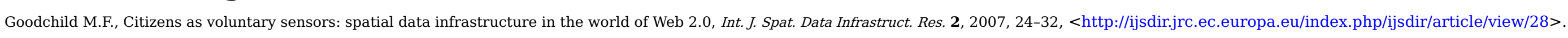

\section{Footnotes}

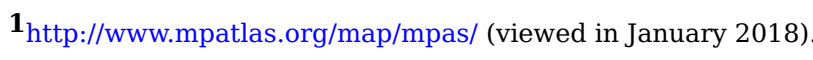

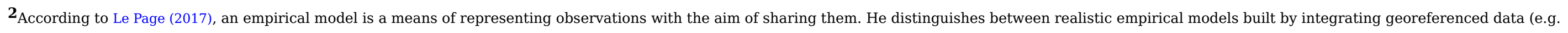
from a Geographic Information System) and stylized empirical models that represent space schematically.

${ }^{3}$ The short film and the results generated by the model can be viewed at this address: www.isis-fish.org

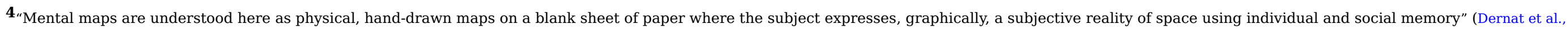
2016).

Abstract

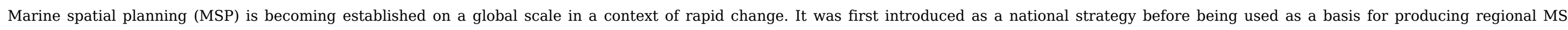

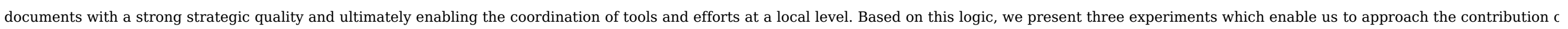

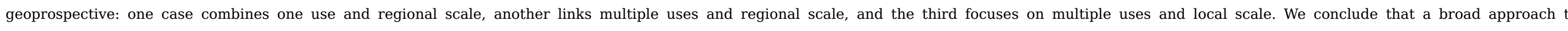

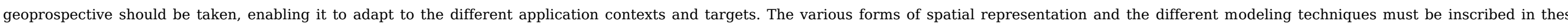
contexts and carefully introduced to ensure that they facilitate rather than hinder an often-fragile collaborative process.

Keywords: Geoprospective process; marine spatial planning; modeling; participation; space; spatial representation 